\title{
A FEASIBILITY STUDY AND COST PERFORMANCE FOR INDUSTRIAL AND COMMERCIAL PRODUCTION OF TRICHOGRAMMA SSP. IN EGYPT
}

\author{
GAFFAR, S. ${ }^{1} *$, M. E.EL-NAGGAR ${ }^{2}$, Z. HENDI ${ }^{3}$ and W. Z. A. MIKHAIL ${ }^{4}$ \\ 1. Central Laboratory of Organic Agriculture, ARC, Center, Giza, Egypt. \\ 2. Agriculture Research Center, Giza, Egypt. \\ 3. Plant Protection Dept., Fac. Of Agric., Ain Shams Univ., Shoubra El-Kheima, Cairo. \\ 4. Dept., Natural Resources, Inst. African Research \&studies, Cairo Univ., 12613 \\ Giza, Egypt. \\ *Corresponding author. Email: Saad_bio_organic@yahoo.com 1
}

(Manuscript received 15 July 2012 )

\begin{abstract}
Biological control of phytophagous insects by mass release of egg parasitoids has become more practical in recent years. Trichogrammatides and other egg parasitoids are generally part of the local ecosystem and often contribute to control certain lepidopterous pests in the absence of disruptive pesticides. The wide use of Trichogrammatides is mostly due to the easy mass production technique of these parasitoids on numerous hosts which are mainly the lepidopterous insect-pests of stored products, such as Sitotroga cerealella (Olivier), Ephestia kuehniella Zeller and Corcyra cephalonica (Stainton). Eggs of the Mediterranean flour moth, E. kuehniella Zell. are widely utilized as substitution host or prey for rearing different parasitoids and predators. The economical production of great amounts of high quality eggs of $\mathrm{E}$. kuehniella is therefore one of the basic requirements of many rearing systems. Consequently, quality control of E. kuehniella is a part of the complete control system in mass production. The main finding indicated that, the cost of production per 1000 parasitoid (one card) is 0.5 LE. Moreover, the capital recovery period after one year estimated $95 \%$.
\end{abstract}

\section{INTRODUCTION}

During the past 120 years, a large number of natural enemies has been collected and evaluated for use in augmentative biological control programmes. Particularly during the last 30 years many efficient species has been identified and currently at least 230 species are commercially available globally (Van Lantern, 2011). Today, the commercial biological control industry is well organized, has developed mass production and release methods as well as adequate guidance for farmers. 
Biological control has been in use for about two millennia, and has become widely used in pest management since the end of the nineteenth century (Van Lantern and Godfray, 2005). Trichogramma spp. are the important biological control agents for lepidopterous pests. Several species of Trichogramma are reared and released around the world annually on an estimated 80 million acres of agricultural crops in 30 countries (Li, 1994, Olkowski and Zhang, 1990). Trichogramma spp. parasitize the eggs over 400 species belonging to at least seven insect orders (Bao and Chen, 1989). Insectaries for mass rearing of Trichogramma using factitious hosts have been constructed in many countries. Wide use of factitious host eggs for mass rearing Trichogramma based on the relative simplicity and comparative low cost of their production when compared with eggs of the target pest.

The objective of present study was conducted to estimate cost of setting up and performance for producing the biocontrol agents, Trichogramma parasitoid in Egypt.

\section{MATERIALS AND METHODS}

Feasibility study was made includes two major tasks: the first major one is to produce the factitious host (unit A), E. kuehniella Zeller and the second major task is to produce, Trichogramma spp. (Unit B) and that's the main target. This study calculates all costs for production during one year. The following inputs were taken in consideration:

1- Fixed Assets.

* Machinery \& Utility.

2- Working Capital.

* Raw Materials (variable cost) (Food and other)/ year.

* Salaries and Over Heads.

The following measurements were taken as criteria for evaluating the obtained data:

1- Fixed Capital (F. C.).

2- Working Capital (W. C.).

3- Total invested capital = F.C. + W.C.

4- Other fixed cost for year.

5- Depreciation.

6- Value of year profit = Value of year production - Other fixed cost. 


\begin{tabular}{|c|c|c|}
\hline \multirow[b]{2}{*}{ 7- Percentage of profit = } & Value of year profit & \multirow[b]{2}{*}{$\times 100$} \\
\hline & Total invested capital & \\
\hline \multirow[b]{2}{*}{ 8- Capital recovery period = } & Value of year profit & \multirow[b]{2}{*}{$\times 100$} \\
\hline & $\begin{array}{c}\text { Value of year profit }+ \\
\text { Depreciation }\end{array}$ & \\
\hline
\end{tabular}

\section{RESULTS AND DISCUSSION}

1. Cost production steps of E. keuhniella and Trichogramma ssp.

1.1. Fixed assets.

Factitious host Unit (A) (E. keuhniella), which containing several machinery, such as Closet for collecting adults of E. keuhniella with total price $90000 \mathrm{LE}$, Movable shelves 36000 LE, Metal trays 8960 LE, Oven 3500 LE, UV machine 3200 LE, Egg laying \&collecting machine 34800 LE (Gaffar, 2006 and Gaffar et al., 2012) and CO2 bottles 5000 LE, with total price of Unit (A) (181460 LE.).

Bio-agent Unit (B) (Trichogramma), which containing several machinery, such as Glass jars total price 450 LE, Ice box 500 LE, Incubator (local) 3000 LE, Cooling room 3000 LE and Wood cells for rearing (400 cell) 1000 LE, with total price of Unit (B) (7950 LE). Finally, the total price of Units $(A+B)=189410$ LE (Table 1 ).

\subsection{Working Capital.}

\subsubsection{Raw Materials (variable cost) (food and other)/ year.}

The raw materials containing Corn and wheat (24 unit $\times 32$ tray $\times$ corn and wheat $1.55 \mathrm{Kg} \times 12$ month $\times 1$ pound) (El- Arnaouty, 2001) with total price 10267.2 LE, CO2 bottles (30 bottle/month $\times 12$ month $\times 29$ pound) 10440 LE (El-Arnaouty, 2001), Manila paper (24 unit $\times 32$ tray $\times 12$ month $\times 0.07$ LE) 645.12 LE (El-Arnaouty, 2001), Equipment for sterilization and maintenance 1200 LE (El-Arnaouty, 2001), White paper (A4) 250 LE, Application cards 320000 LE, Honey 80 LE and Glue 45 LE, with total raw materials price 342927.3 LE (Table 2).

The following measurements were taken as criteria for evaluating the obtained data: 


\subsubsection{Fixed Capital (F.C.):}

Containing Building cost/300 m² with 300000 LE, Machinery and utility 189410 LE, Cars and transporting 120000 LE, Furniture cost 10000 LE and Costs before production 6000 LE with Fixed Capital total price 625410 LE.

\subsubsection{Working Capital (W.C.):}

Containing Rents/one year 18000 LE, Salaries/3 months 8100 LE, Water and electricity/3 months according to statistics 2400 LE (El Arnaouty, 2001), Gas costs/ 3 months 1500, Marketing costs/3 months 4500 LE and Other costs/3 months 1500 LE with Working Capital total price 36000 LE (Table 3).

1.3. Total invested capital $=$ F.C. + W.C.

Total invested capital $=625410+36000=661410$ LE.

1.4. Other fixed cost for year:

Containing Rents 18000 LE, Preservation expended 6000 LE, Salaries 32400 LE, Raw materials 342927.3 LE, Energy of electricity and water 9600 LE, Gas 6000 LE, Marketing costs 18000 LE, Other costs 6000 LE and the total of operating expended 438927.3 LE (Table 4).

\subsection{Depreciation:}

The depreciation of the year are, Machinery \& Utility 18941 LE, Building cost 15000 LE, Furniture 1000 LE and cars 24000 LE, with Total depreciation per day 58941 LE (Table 5).

2. Estimation of the production costs of Trichogramma ssp.

Data in Table 6 showed the prices of all raw materials in Egypt during 2006 and indicate that the price of one card of Trichogramma equal 0.5 LE. The present results are going on a line with those obtained by Garcia, 1982 who found that the cost was about $\$ 0.02$ (0.11 LE) per 1000 parasitoids. Such finding is in agreement with that obtained by Burbutis and Goldstein, 1993 and Goldstein et al. 1993. They found that cost was about $\$ 0.12$ (0.66 LE) per 1000 parasitoids. And the value of year were profit reached, $1073072.7 \mathrm{LE}$. The percentage of profit recorded $162.24 \%$.

Fig. (1) showed that capital recovery period after the $1^{\text {st }}$ year were $95 \%$ from the fixed assets and costs.

\section{Final considerations.}

As shown in this study, a calculate method the feasibility study to helpful researchers to economic production for any bioagents. The objective of mass rearing of E. keuhniella is to maximize production of eggs at the lowest possible costs, i.e. defining optimal rearing methodology. Our economic method studying showed the success of mass rearing the Mediterranean flour moth depends on a physical conditions and different machinery for each rearing stages. Therefore, process and production steps with their costs. 
Table 1. Machinery and utility in mass production.

\begin{tabular}{|c|c|c|c|c|c|}
\hline Unit & Serial & Machinery & Price of unit (LE) & Number & Total price (LE) \\
\hline \multirow{8}{*}{ 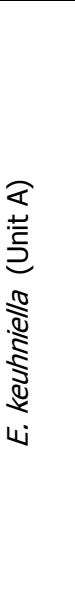 } & 1 & $\begin{array}{l}\text { Closet for collecting adults of } \\
\text { E. keuhniella }\end{array}$ & 4500 & 20 & 90000 \\
\hline & 2 & Movable shelves & 1800 & 20 & 36000 \\
\hline & 3 & Metal trays & 14 & 640 & 8960 \\
\hline & 4 & Oven & 3500 & 1 & 3500 \\
\hline & 5 & UV machine & 3200 & 1 & 3200 \\
\hline & 6 & $\begin{array}{l}\text { Egg laying \& collecting } \\
\text { machine }\end{array}$ & 6960 & 5 & 34800 \\
\hline & 7 & CO2 bottles & 500 & 10 & 5000 \\
\hline & \multicolumn{4}{|c|}{ Total (A) } & 181460 \\
\hline \multirow{7}{*}{ 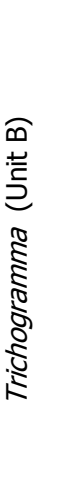 } & 8 & Glass jars & 1.5 & 300 & 450 \\
\hline & 9 & Ice box & 500 & 1 & 500 \\
\hline & 10 & Incubator (local) & 3000 & 1 & 3000 \\
\hline & 11 & Cooling room & 3000 & 1 & 3000 \\
\hline & 12 & $\begin{array}{l}\text { Wood cells for rearing (400 } \\
\text { cell) }\end{array}$ & 1000 & - & 1000 \\
\hline & \multicolumn{4}{|c|}{ Total (B) } & 7950 \\
\hline & \multicolumn{4}{|c|}{ Total $(A+B)$} & 189410 \\
\hline
\end{tabular}

Table 2. Raw materials (Variable cost) (food and others) for one year.

\begin{tabular}{|l|c|c|c|c|}
\hline \multicolumn{1}{|c|}{ Materials } & Unit & Quantity & Price of unit/LE & Total price (LE) \\
\hline $\begin{array}{l}\text { Corn and wheat }(24 \text { unit } \times 32 \text { tray } \\
\times 1.55 \mathrm{~kg} \times 12 \text { month } \times 1 \mathrm{LE})\end{array}$ & $\mathrm{kg}$ & 10267.2 & 1 & 10267.2 \\
\hline $\begin{array}{l}\text { CO2 bottles }(30 \text { bottle/month } \times 12 \\
\text { month } \times 29 \mathrm{LE})\end{array}$ & Bottle & 360 & 29 & 10440 \\
\hline $\begin{array}{l}\text { Manila paper }(24 \text { unit } \times 32 \text { tray } \times \\
12 \text { month } \times 0.07 \text { LE) }\end{array}$ & Paper & 9216 & 0.07 & 645.12 \\
\hline $\begin{array}{l}\text { Equipment for sterilization and } \\
\text { maintenance }\end{array}$ & /month & 12 & 100 & 1200 \\
\hline White paper (A4) & Ream & 10 & 25 & 250 \\
\hline Application cards & Million & 4 & 0.08 & 320000 \\
\hline Honey & $\mathrm{Kg}$ & 4 & 20 & 45 \\
\hline Glue & $\mathrm{Kg}$ & 3 & 15 & \\
\hline Total & & & 342927.3 & \\
\hline
\end{tabular}


Table 3. Total invested capital.

\begin{tabular}{|c|c|c|c|}
\hline Serial & Fixed capital/year & Cost/LE & Total cost/LE \\
\hline 1 & Building cost/ $300 \mathrm{~m}^{2}$ & 300000 & \\
\hline 2 & Machinery and utility & 189410 & \\
\hline 3 & Cars and transporting & 120000 & \\
\hline 4 & Furniture cost & 10000 & \\
\hline 5 & Costs before production & 6000 & \\
\hline \multicolumn{3}{|c|}{ Total of fixed capital } & 625410 \\
\hline Serial & \multirow[t]{2}{*}{ Working capital } & Cost/LE & Total cost/LE \\
\hline 1 & & 18000 & \\
\hline 2 & Salaries/ 3 months & 8100 & \\
\hline 3 & Water and electricity/ 3 months according to statistics & 2400 & \\
\hline 4 & Gas costs/ 3 months & 1500 & \\
\hline 5 & Marketing costs/ 3 moths & 4500 & \\
\hline 6 & Other costs/ 3 months & 1500 & \\
\hline \multicolumn{3}{|c|}{ Total of working capital } & 36000 \\
\hline \multicolumn{3}{|c|}{ Total invested capital } & 661410 \\
\hline
\end{tabular}

Table 4. Other fixed cost for year.

\begin{tabular}{|c|l|c|}
\hline Serial & \multicolumn{1}{|c|}{ Operating expended } & Cost/LE \\
\hline 1 & Rents & 18000 \\
\hline 2 & Preservation expended & 6000 \\
\hline 3 & Salaries & 32400 \\
\hline 4 & Raw materials & 342927.3 \\
\hline 5 & Energy of electricity and water & 9600 \\
\hline 6 & Gas & 6000 \\
\hline 7 & Marking costs & 6000 \\
\hline 8 & Other costs $\quad$ Total of operating expended & 438927.3 \\
\hline
\end{tabular}


Table 5. Deprecation value.

\begin{tabular}{|c|l|c|c|}
\hline Serial & Materials & Deprecation \% for year & Value of deprecation LE \\
\hline 1 & Machinery \& Utility & 0.10 & 18941 \\
\hline 2 & Building cost & 0.05 & 15000 \\
\hline 3 & Furniture & 0.10 & 1000 \\
\hline 4 & Cars & 0.20 & 24000 \\
\hline \multicolumn{2}{|r|}{ Total deprecation per day } & 58941 \\
\hline
\end{tabular}

Table 6. Total costs of bio-company for Trichogramma.

\begin{tabular}{|c|c|c|c|c|c|}
\hline \multirow{2}{*}{} & \multirow{2}{*}{ Producible } & \multicolumn{3}{|c|}{ Productive potential/year } & \multirow{2}{*}{$\begin{array}{c}\text { Total } \\
\text { Salaries L.E }\end{array}$} \\
\cline { 3 - 5 } & Quantity & Unit & Salary price/ LE & \\
\hline \multirow{2}{*}{1} & $\begin{array}{c}\text { Card Trichogramma } \\
\text { (2 waves). }\end{array}$ & 3024000 & Card & 0.5 & $1,512,000$ \\
\hline
\end{tabular}

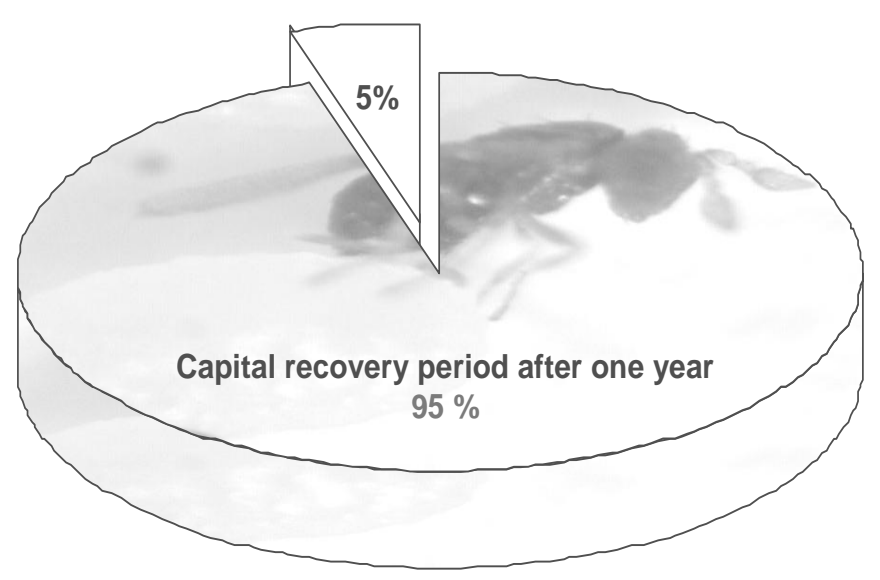

Fig. 1.The capital recovery period after one year. 


\section{REFERENCES}

1. Bao, J. Z. and X. H. Chen. 1989. Research and applications of Trichogramma in China. Academic Books and periodicals press, Beijing. PP.220.

2. Burbutis, P. P. and L. F. Goldstein. 1993. Mass rearing Trichogramma nubilale on European corn borer, its natural host. Production Ecology, 5: 269- 275.

3. El-Arnaouty, S. A. 2001. Technical improvements in mass rearing of Ephestia kuehniella Zeller (Lep.: Pyralidae) as a substitution prey for a cost effective production of Chrysoperla carnea Steph. Integrated Pest Management, Proc. Of the 1st Congress, Cairo Univ., Fac. Agric., 22-23 April, Part I, 42-52.

4. Gaffar, S. 2006. Some factors affecting parasites on potential of some Trichogramma parasitoid species under mass rearing conditions. M Sc. Thesis, Institute of African Research and Studies. Cairo Univ., 145 PP.

5. Gaffar, S., M. E. Naggar and W. Z. A., Mikhail. 2012. A novel technique for commercial mass production of natural enemies for using in applied biological control. Egypt. J. Agric. Res., 90(3): 1245-1255.

6. Garcia, V. (1982): Estimate of the cost of setting up a mass-production unit of Trichogramma in the Azores. Trichogramma 1st Symposium International, Antibes, 20-23 April, 1982, Paris, France: 183-189.

7. Goldstein, L. F., P. P. Burbutis and D. G. Ward. 1993. Rearing Trichogramma nubilale (Hym.: Trichogrammatidae) on Ultraviolet-Irrigated eggs of European corn borer (Lep.: Pyralidae). J. Econ. Entomol., 76: 969-971.

8. Li, L. Y. 1994. Worldwide use of Trichogramma for biological control on different crops, A survey. In: Biological control with egg parasitoids (eds. E. Wanjnberg and S. A. Hassan), PP. 37-53.

9. Olkowski, W. and A. Zhang. 1990. Trichogramma modern day frontier in biological control. The IPM Practit., 12: 1-15.

10. Van Lantern, J. C. 2011. The state of commercial augmentative biological control: plenty of natural enemies, but a frustrating lack of uptake. Biocontrol (1): $1-20$.

11. Van Lantern, J. C. and H. C. J. Godfray. 2005. European Science in the Enlightenment and the discovery of the insect parasitoid life cycle in the Netherlands and Great Britain. Biol. Control. 32: 12-24. 
دراسة جدوى وتكاليف الآداء للإتتاج الصناعى والتجارى للتريكوجراما فى مصر لمانساع

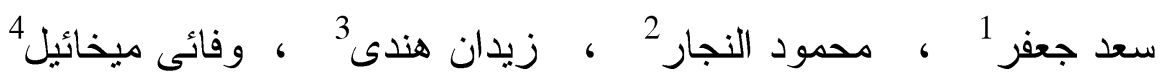

$$
\begin{aligned}
& 1 \text { الدعمل المركزى للزراعة العضوية ، مركز البحوث النراعية ، الجبزة ، مصر } \\
& 2 \text { مركز البحوث الزراعية ، الجبزة ، مصر فرع } \\
& 3 \text { قسم وقاية النبات، كلية الزراعة، جامعة عبن شصس ، شيرا الخيهة ، القاهرة ، مصر } \\
& 4 \text { قسم الدوارد الطبيعية ، معهز البحوث والدراسات الأفريقية ، جامعة القاهرة }
\end{aligned}
$$

Corresponding author. Email: Saad_bio_organic@yahoo.com ${ }^{1}$

أصبحت المكافحة الحيوية للحشرات نباتية التغذية بطفيليات البيض التى يتم

تربيتها و المستخدمة فى الإطلاق أكثر واقعية فى السنين القريبة. تعتبر التريكوجراما

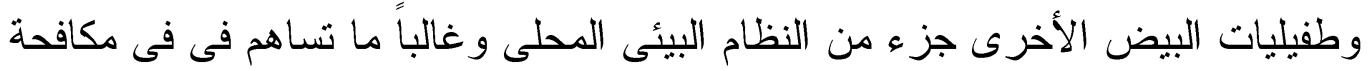

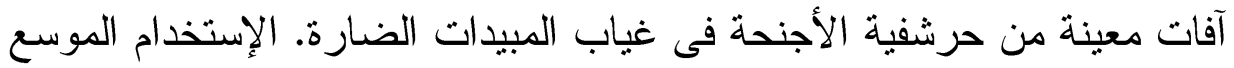

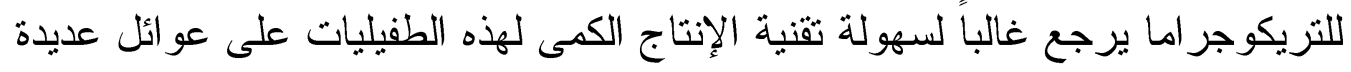

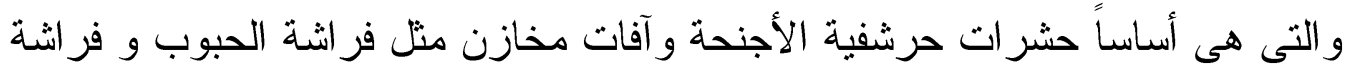

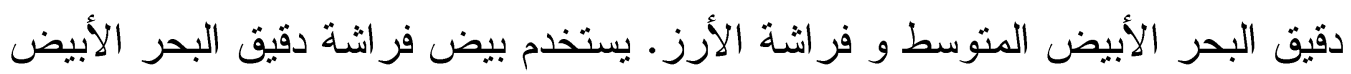

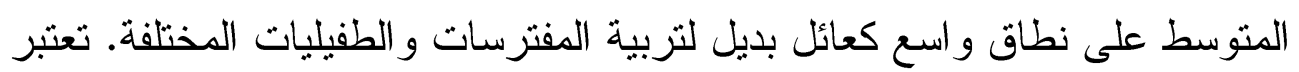

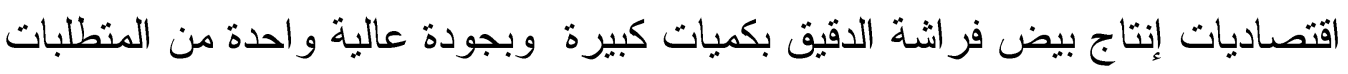

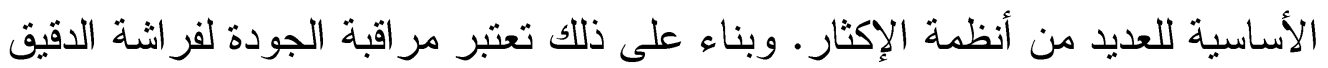

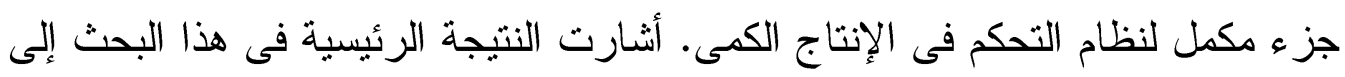
ان تكاليف إنتاج 1000 طفيل تريكوجر اما (كارت واحد) كانت 0,5 جنيه مصرى. علاوة على ذلك، كان العائد من تكاليف رأس المال المستثر بعد أول سنة حوالى

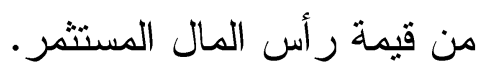

